\title{
Hudebně-pedagogické oddělení Ukrajinského vysokého pedagogického ústavu Mychajla Drahomanova v Praze (1923-1933)
}

\section{The Music Education Section of the Mykhailo Drahomanov Ukrainian Higher Pedagogical Institute in Prague (1923-1933)}

Petr Ch. Kalina / 17113@mail.muni.cz

Department of Musicology, Faculty of Arts, Masaryk University, Brno, CZ

\begin{abstract}
During 1923-1933, the Mykhailo Drahomanov Ukrainian Higher Pedagogical Institute operated in Prague, providing advanced education to Ukrainian émigrés who settled in Czechoslovakia during the interwar period. Beyond the primary function of the institute's music education faculty - to train teachers for Ukrainian secondary schools - it became the organising focal point of Ukrainian musical life in Prague, as well as an important centre of Ukrainian musicological research in Czechoslovakia. The Prague Drahomanov Institute was the first, and so far the only, place in Ukrainian education where music was taught as in a university - i.e. in close contact with the humanities and social sciences, as is the norm in Western Europe - and not, as it were, in a conservatoire, where musicology and music education are solely the preserve of academies of art, the arrangement more common in the post-Soviet region.
\end{abstract}

\section{Keywords}

Mykhailo Drahomanov Ukrainian Higher Pedagogical Institute in Prague, Ukrainian music, interwar Czechoslovakia, music education 
V souvislosti s krachem národně-obrozeneckých snah Ukrajinců po první světové válce, jenž měl za následek začlenění ukrajinských zemí zejména do struktur Sovětského svazu a Polska, zaznamenáváme značnou vlnu emigrace příslušníků ukrajinského národa směrem na západ. Bylo to právě meziválečné Československo, jež se stalo důležitým centrem politického, kulturního i společenského života ukrajinské diaspory, která ve sledované době čítala v Československu kolem dvou desítek tisíc osob.

Ukrajinci, kteří na našem území našli svou novou vlast, zakládali kromě řady jiných institucí především v Praze a blízkém okolí vlastní edukační střediska, která nabízela předškolní, středoškolské a zejména vysokoškolské vzdělání. Nutno říci, že tato školská centra si do značné míry žila vlastním životem. Byla totiž takřka výhradně zaměřena na samotnou ukrajinskou komunitu a s domovskou společností hostitelského státu byla propojena jen minimálně. Z tohoto důvodu zaznamenal sledovaný fenomén nulový nebo jen minimální ohlas v řadách příslušníků většinové domácí society a jeho existence byla drtivé většině Čechoslováků zcela neznámá. Obecné povědomí o poměrně bohatých kulturních, spolkových a edukačních aktivitách ukrajinské diaspory ve 20. a 30. letech 20. století v Československu (jež se realizovaly především v Praze a Středočeském kraji) není o nic větší ani dnes s odstupem osmi až devíti desítek let.

Z předškolních zařízení fungoval v Čechách Ukrajinský dětský útulek V Horních Počernicích a později v Poděbradech založený pro ukrajinské sirotky, potomky studentek a děti z nemajetných rodin, z něhož se později stala ukrajinská měštanská škola (1925-1939), ${ }^{1}$ střední školou bylo Ukrajinské gymnázium v Praze, které posléze přesídlilo do středočeských Řevnic a dále do Modřan (1924-1945), ${ }^{2}$ z vysokých škol potom Ukrajinská svobodná univerzita v Praze (1921-1945), Ukrajinská hospodářská akademie v Poděbradech (1923-1932), Ukrajinské studio výtvarného umění v Praze (1923-1945) a pro naše účely klíčový Ukrajinský vysoký pedagogický ústav Mychajla Drahomanova (1923-1933). Dlouhodobým cílem ukrajinské diaspory bylo také vytvoření sítě ukrajinských základních škol, tyto jejich snahy však nedošly naplnění, a tak základní školy v systému ukrajinského školství v Československu chybějí (v této souvislosti dodejme, že v předkládané studii záměrně nereflektujeme situaci ukrajinského vzdělávání na Podkarpatské Rusi, kde v tomto ohledu panovala specifická situace).

Předpokládáme, že s určitým druhem hudební edukace jsme se mohli setkat v Ukrajinském dětském útulku a prokazatelně také na Ukrajinském gymnáziu, centrem naší pozornosti však budou vysoké školy, v nichž k hudebnímu vzdělávání docházelo na systematické úrovni. Z vysokých škol tedy necháme stranou Ukrajinskou hospodářskou akademii v Poděbradech a Ukrajinské studio výtvarného umění, jelikož zde se žádné hudební předměty nevyučovaly a studenti těchto institucí se mohli hudebně vzdělávat jen ve svém volném čase, a to zejména aktivní participací na činnosti Ukrajinského akademického sboru, který ve svých řadách sdružoval v Čechách studující ukrajinské vysokoškoláky.

1 НАРІЖНИЙ, Симон. Українська еміграція. Культурна праця української еміграції 1919-1939. Ч. 2. Київ: Видавнициво ім. Олени Теліги, 1999.

2 МАРУНЯК, В. (еd.): Українська гімназія в Чехії. 1925-1945. Альманах Української гімназії в Празі - Ржевніцах - Модржанах. München 1975. 
K hudebnímu vzdělávání na ukrajinských vysokých školách v Československu tak docházelo pouze na Ukrajinské svobodné univerzitě a na Ukrajinském vysokém pedagogickém ústavu Mychajla Drahomanova. První ze zmíněných vysokých škol byla nestátní emigrantskou univerzitou vybudovanou podle západoevropských vzorů. Založena byla roku 1921 ve Vídni, v tomtéž roce však byla přestěhována do Prahy. Ukázalo se totiž, že největší množství ukrajinské mládeže, která dychtí po vysokoškolském vzdělání ve svém jazyce, se nachází právě zde. ${ }^{3}$ Pedagogické kolegium univerzity sestávalo zejména z ukrajinských vysokoškolských pedagogů a vědců, kteří z politických důvodů opustili své domovské ruské a polské univerzity na ukrajinském území. Poté, co byly ve dvacátých letech na západní Ukrajině, která patřila k Polsku, zrušeny ukrajinské katedry na univerzitách ve Lvově a v Černovicích a na tzv. velké Ukrajině patřící pod nově vzniklý Sovětský svaz se bud' zrušily, nebo zreformovaly ukrajinské vysoké školy, ${ }^{4}$ stala se v Praze sídlící Ukrajinská svobodná Univerzita na určitý čas jedinou ukrajinskou vysokou školou na světě. Není bez zajímavosti, že Ukrajinskou svobodnou univerzitu nepostihl po roce 1939 osud českých vysokých škol a mohla tak nabízet vzdělání ukrajinským studentům i v době protektorátu. Škola tehdy podléhala dohledu rektora Německé Karlovy univerzity. Po osvobození Československa Rudou armádou se univerzita přesunula do americké okupační zóny Německa, ${ }^{5}$ konkrétně do Mnichova, kde ve výrazně omezené míře působí prakticky dodnes.

Ukrajinská svobodná univerzita měla v době své pražské existence dvě fakulty - filozofickou a fakultu práva a př́rodních věd. Na filozofické fakultě existovalo Historicko-filologické oddělení, na němž se každý semestr vypisovaly hudební přednášky a semináře. Jejich témata zahrnovala následující okruhy: dějiny ukrajinské i světové hudby, hudební teorie, hudební paleografie a hudební bibliografie. Učitelem těchto předmětů byl takřka po celou dobu fungování této instituce ukrajinský muzikolog a někdejší žák Mykoly Lysenka Fedir Steško, o jehož činnosti jsme před časem v tomto časopise podrobně informovali $^{6}$ a o němž se v této stati budeme ještě zmiňovat v souvislosti s hudebně-pedagogickou institucí, jež naším ústředním tématem. Předměty týkající se hudby se na Ukrajinské svobodné univerzitě vyučovaly jen okrajově.

Ukrajinská svobodná univerzita nabízela také doktoráty z hudební vědy. Své disertační práce v tomto oboru zde však obhájili pouze dva uchazeči; šlo o Zenovije Lyska ${ }^{7}$ a Stefanii Trukevyč-Lisovskou. ${ }^{8}$ Školitelem jejich disertací byl v obou případech muzikolog, estetik a pozdější komunistický ministr Zdeněk Nejedlý, který byl v meziválečné době kulturní i politické emancipaci ukrajinského národa výrazně nakloněn.

3 Український вільний університет в Прахі, в роках 1921-1922. Прага: Державна друкарня, 1924.

4 RYCHLÍK, Jan - ZILYNSKYJ, Bohdan - MAGOCSI, Paul Robert. Dějiny Ukrajiny. Praha: Nakladatelství Lidové noviny, 2015.

5 Український вільний університет. Короткий огляд. Мюнхен: Український вільний університет, 1958 / Ukrainian Free University. Short Review. Munich: Ukrainian Free University Press, 1958.

6 KALINA, Petr Ch. Pražské působení ukrajinského muzikologa Fedora Steška. Musicologica Brunensia, 47, 2012, č. 2, s. 49-63.

7 KALINA, Petr Ch. Zenovij Lysko, ukrajinský žák Josefa Suka. Opus musicum, 49, 2017, č. 2, s. 25-41.

8 Центральний державний архів вищих органів влади і управління України. Ф. 3956, оп. 1, спр. 33: Дисертація С. Туркевич-Лісовської «Українські елементи в операх Чайковського Черевички та Римського-Корсакова Ніч перед Різдвом і порівнання їх з оперою Лисенка Різдвяна ніч». 
Nepoměrně systematičtěji se hudbě věnovala pozornost na Ukrajinském vysokém pedagogickém ústavu, který přijal jméno významného ukrajinského politika 19. století Mychajla Drahomanova. ${ }^{9}$ Tato škola vznikla v Praze v roce 1923 péčí Ukrajinského občanského výboru, ${ }^{10}$ což byl spolek, který se zpočátku staral především o materiální a zdravotnickou pomoc ukrajinským emigrantům v Československu, později však také o jejich kulturní a vzdělávací potřeby. Zřizovatelem školy a hlavním poskytovatelem financí na její provoz se stalo československé Ministerstvo zahraničních věcí řízené Edvardem Benešem. Dne 4. května 1923 schválilo ministerstvo stanovy školy a 17. srpna byla zahájena výuka. Ústav zpočátku neměl vlastní sídlo; přednášky se konaly v budově reálné školy v Ječné ulici, v prostorách reálného gymnázia v Křemencově ulici, na Přírodovědecké fakultě Univerzity Karlovy na Albertově a na dalších místech. V roce 1926 začala škola sídlit v ulici Školská č. 8. Při Ústavu vzniklo nakladatelství Sijač, ${ }^{11}$ které vydávalo učebnice a vědecké publikace v ukrajinštině. ${ }^{12} \mathrm{~V}$ čele školy stál nomenklaturně rektor s prorektorem. Struktura výuky byla organizována podle vzoru západoevropských vysokých škol s přednáškami a semináři, ročníkovým systémem a dělením na semestry. Akademický personál se skládal z profesorů, docentů, asistentů a lektorů. Studium bylo bezplatné a vyučovacím jazykem byla ukrajinština ${ }^{13}$ (na škole však působilo několik českých lektorů, kteří přirozeně vyučovali česky). Slavnostní zahájení činnosti Ústavu se konalo 7. července 1923 ve velké posluchárně Geologického ústavu Univerzity Karlovy, kde zazněly zdravice prezidenta republiky, premiéra a několika československých ministrů.

Úkolem nového pedagogického pracoviště bylo především vzdělávání budoucích učitelů, kteří se měli uplatňovat na ukrajinských obecných a měštanských školách, učitelských seminářích, gymnáziích a reálných školách v Čechách a na Podkarpatské Rusi (nutno však dodat, že takto široká sít ukrajinského školství v Československu nakonec ani zdaleka vybudována nebyla), př́ípadně i na ukrajinském území. S uplatněním absolventů na československých školách (resp. na školách s vyučovacím jazykem československým) se nepočítalo. Studenti absolvovali pedagogické praxe na Ukrajinském gymnáziu, které pod vysoký pedagogický ústav formálně spadalo. Učitelský sbor školy Mychajla Drahomanova se skládal nejen z vlastních kmenových pracovníků, ale také z externích pedagogů z řad učitelo̊ Ukrajinské svobodné univerzity, Univerzity Karlovy nebo pražské konzervatoře. Na škole studovali v drtivé většině emigranti z takřka všech ukrajinských zemí (převládali někdejší obyvatelé naddněperské Ukrajiny, která byla dříve součástí carského Ruska a ve sledované době tvořila Ukrajinskou sovětskou socialistickou republiku), kromě Ukrajinců se tu však učili i Bělorusové, Češi, Židé, Bulhaři a ojediněle i osoby srbské, rumunské,

9 Український високий педагогічний інститут ім. Михайла Драгоманова у Празі.

10 Український громадський комітет.

11 Сіяч

12 HAVEL, Ondřej Osudy ukrajinské emigrace v první československé republice se zaměřením na vysoké školství (Ukrajinský vysoký pedagogický institut Mychajla Drahomanova). Disertační práce, Filozofická fakulta Univerzity Palackého v Olomouci, Olomouc 2012.

13 Імені Драгоманова. До 75-ї річниці заснування Українського Високого Педагогічного Інституту в Празі. Український світ, 7, 1998, № 4-6, s. 13. 
gruzínské a arménské národnosti. Ku podivu zde téměř nestudovali Ukrajinci (Rusíni) z Podkarpatské Rusi. ${ }^{14}$

Ústav byl založen jako vyšší odborná pedagogická škola se standardně tříletým studiem ${ }^{15}$ a už při jeho vzniku zde fungovala hudebně-pedagogická katedra. Ve druhém akademickém roce (1924/1925) došlo k restrukturalizaci ústavu, který se tak stal plnohodnotnou vysokou školou s čtyřletou délkou studia. Škola měla od té doby právo udělovat doktoráty, později vedla samostatná habilitační řízení i řízení ke jmenování profesorem. Tehdy se profesorský sbor školy rozhodl dát hudbě, která je z uměleckých druhů pro Ukrajinu nejtypičtější, větší prostor než doposud a požehnal transformaci hudebně-pedagogické katedry na samostatné hudebně-pedagogické oddělení, jež bylo běžně nazývané fakultou. ${ }^{16}$ Hudební vzdělávání tak na škole získalo značnou autonomii. Oddělení mělo za úkol připravovat učitele středních škol v hudbě, aby se tito pedagogové později podíleli na povznesení hudební kultury na Ukrajině. Hudebně-pedagogické oddělení mělo čtyři katedry. Byla to Katedra hudební teorie a kompozice, Katedra dějin hudby, Katedra hudební etnografie a Katedra hudební akustiky a psychofyziologie. Předměty vypisované katedrami navštěvovali všichni posluchači oddělení. Kromě toho zde fungovaly čtyři pedagogické třídy: klavírní, houslová, sbormistrovská a třída sólového zpěvu, což byly zároveň jednotlivé obory, které se daly na Hudebně-pedagogickém oddělení studovat. Za dobu existence oddělení zde studovalo 63 osob. ${ }^{17}$

Studium bylo standardně ukončeno složením diplomové zkoušky, které předcházelo splnění všech povinných zkoušek, kolokvií a zápočtů během studia a pedagogické praxe v podobě vykonání vzorové vyučovací hodiny před komisí na střední škole. Mezi předměty společného základu u diplomové zkoušky patřily dějiny pedagogiky, vzdělávací systém, logika, didaktika, hygiena, český jazyk, německý jazyk, ukrajinský jazyk, politická ekonomie, sociologie, úvod do filosofie a dějiny filosofie. Studenti Hudebně-pedagogického oddělení pak museli absolvovat tyto oborové předměty: základy hudební teorie, hudební akustika a psychofyziologie, organologie, dějiny hudby, harmonie, kontrapunkt, hudební formy, intonace, hudební etnografie, dějiny umění, dějiny Ukrajiny, ukrajinská literatura, hra na klavír, teorie pedagogiky a pedagogická psychologie. Podle vybraného oboru potom posluchači museli úspěšně ukončit předmět teorie a praxe zpěvu a sbormistrovství, teorie a praxe sólového zpěvu, hra na klavír a jeho historicko-systematická problematika, nebo hra na housle a jejich historicko-systematická problematika.

14 МІРНИЙ, Іван. Український високий педагогічний інститут ім. М. Драгоманова 1923-1933 (iсторія інституту). Прага: Високий педагогічний інститут за допомогою Міністерства шкільництва й народної освіти Ч.С.Р.,1934.

15 НАРІЖНИЙ, Симон. Українська еміграція. Культурна праця української еміграції між двома світовими війнами. Ч. 1. Прага: Knihtisk, 1942.

16 Oficiálně nesly samostatné složky školy označení „oddělení“ (v dokumentech v ukrajinštině „відділ“). Dle jejich vnitřní i vnější struktury však šlo de facto o fakulty a v jejich čele stál nomenklaturně děkan. HAVEL, Ondřej. Osudy ukrajinské emigrace v první československé republice se zaměřením na vysoké školství (Ukrajinský vysoký pedagogický institut Mychajla Drahomanova). Disertační práce, Filozofická fakulta Univerzity Palackého v Olomouci, Olomouc 2012.

17 МАРТИНЕНКО, Оксана. Українська музична освіта в Чехії. Музично-педагогічний відділ УВПІ ім. М. Драгоманова. Український світ, 7, 1998, № 4-6, s. 30-31. 
Po složení závěrečné souborné zkoušky byl absolventovi přidělen titul „pedagog středních škol“. ${ }^{18}$

Podmínkou pro získání doktorské zkoušky bylo za prvé řádné absolvování Drahomanovova ústavu nebo filosofické či přrírodovědecké fakulty západoevropského typu, případně absolutorium na historicko-filosofické či matematicko-fyzikální fakulty ruského typu; v jiných případech stačila pouze učitelská praxe na střední škole. Kandidáti na doktora hudebně-pedagogických věd měli za povinnost před rigorózem prokázat znalost harmonie a kontrapunktu. Samotná doktorská zkouška se skládala z obhajoby disertační práce a z komisionální ústní zkoušky. Disertační práce musela být napsána ukrajinsky a obsahovat původní výsledky bádání. Text posuzovala dvojice referentů. Na Hudebně-pedagogickém oddělení bylo nařízeno, že disertace musí mít vědecko-teoretickou povahu. Veřejná komisionální ústní zkouška sestávala z dvou rigoróz - dvouhodinového a hodinového. Předmětem dvouhodinového rigoróza byla disciplína tématu disertace a dále disciplíny některé z příbuzných kateder; tyto obory si kandidát vybíral sám. U hodinového rigoróza byly na všech odděleních Ústavu prověřovány kandidátovy historicko-teoretické znalosti z filozofie a pedagogiky. Úspěšní kandidáti na Hudebně pedagogickém oddělení obdrželi titul „doktor hudebně-pedagogických věd“. ${ }^{19}$ V roce 1930 zde doktorát obhájil Dmytro Ravyč s disertací na téma „Ukrajinská umělá píseň - historický přehled jejího vývoje“, o rok později Antin Jakovlenko s prací „Hudba k Natalce Poltavce“, roku 1932 Pavlo Macenko s tématem disertace „Složení a technická stavba melodií kyjevského zpěvu v Počajivském Irmologu“ a téhož roku Stepan Masljak s tématem "Jazz na pozadí současnosti“. ${ }^{20}$

Na místo děkana Hudebně-pedagogického oddělení byl v době jeho vzniku z petrohradské konzervatoře povolán skladatel a klavírista Fedir Jakymenko (často psán též Akymenko). Tento někdejší zpěvák carské dvorní kapely, narozený roku 1876 v Charkově, absolvoval třídu kompozice petrohradské konzervatoře, kde studoval u Nikolaje Rimského-Korsakova a Anatolije Ljadova. ${ }^{21}$ Navštěvoval také hodiny klavírní hry u Milije Balakireva. Jakymenko kromě děkanské funkce na Hudebně-pedagogickém oddělení Drahomanovova ústavu zastával post vedoucího Katedry hudební teorie a kompozice a měl rovněž dohled nad třídou dirigování, kterou vedla Platonida Ščurovska (později Ščurovska-Rosinevyč). Jeho pedagogickým vedením prošli významní západoukrajinští hudebníci, kteří ve dvacátých letech studovali v Praze, jako např. Mykola Kolessa nebo Zenovij Lysko. Jakymenko v Praze vystupoval coby klavírista a dirigent ukrajinských sborů na večírcích ukrajinské kultury. V hlavním městě Československa rovněž začal harmonizovat ukrajinské lidové písně. Jako skladatel např. v roce 1924 zhudebnil první tři sloky básně, kterou v roce 1876 věnoval Mychajlu Drahomanovovi ukrajinský literát Mychajlo

18 Центральний державний архів вищих органів влади та управління України, Фонд 3972, оп. 1, спр. 176 Постановка професорської ради про дипломні іспити.

19 МІРНИЙ, Іван. Український високий педагогічний інститут ім. М. Драгоманова 1923-1933 (історія інституту). Прага: Високий педагогічний інститут за допомогою Міністерства шкільництва й народної освіти Ч.С.Р., 1934.

20 Центральний державний архів вищих органів влади та управління України, Фонд 3859, оп. 1, спр. 176: Справа про захист дисертацій докторандами університету.

21 МАЦЕНКО, Павло. Якименко Федір Степанович. Вінніпег: Культура й Освіта, 1954. 
Staryckyj Na provody (Na rozloučenou), když Drahomanov odjížděl do vyhnanství, odkud se již nevrátil. Skladba byla otištěna v tzv. Drahomanovském sborníku Ukrajinského vysokého pedagogického ústavu, který ukrajinská pražská škola svému patronovi věnovala. ${ }^{22}$

Vinou toho, že se celý život pohyboval v ruském, českém nebo francouzském prostředí, neovládal Jakymenko ukrajinštinu. V Praze se sice ukrajinsky začal učit, ovšem jeho znalosti tohoto jazyka zůstaly nedostatečné, a proto byl nucen přednášet rusky. Na Drahomanovově ústavu měl kvůli tomuto faktu osobní neshody s některými kolegy, kteří mu vyčítali, že se přiživuje na Ukrajincích a sám ani neumí ukrajinsky. Po dvou letech působení se tedy rozhodl nevrátit se z dovolené v Nice (kde dř́ive v letech 1903-06 působil jako učitel na hudební škole) a ani studenti, u nichž měl vždy značný respekt, jej nepřesvědčili, aby v Praze zůstal. Usadil se v Pařiži, kde později v době druhé světové války materiálně strádal a v roce 1945 zde zemřel. ${ }^{23}$ Jeho v Praze vydaná ukrajinská učebnice Praktyčnyj kurs harmoniji (původně napsaná rusky) z roku 1926 je první prací svého druhu v ukrajinské hudebně-teoretické literatuře. ${ }^{24}$ Plánovaná druhá část učebnice, jež se měla věnovat novým harmonickým systémům, kvůli Jakymenkovu odchodu z Prahy nevyšla. ${ }^{25}$

Vyučovací předměty po Jakymenkovi převzal profesor pražské konzervatoře Otakar Š́n ${ }^{26}$ a na uvolněné děkanské místo nastoupil již zmíněný Fedir Steško, který ve funkci setrval až do ukončení činnosti této školy v roce 1933. Steško zde působil jako lektor už od založení ústavu. Byl v kolektivu pedagogů hudebně-pedagogického oddělení Drahomanova ústavu v podstatě jediný, kdo byl schopen učit obecné předměty historické a systematické muzikologie. Vyučoval zde dějiny světové hudby, dějiny ukrajinské hudby, hudební etnografii, hudební estetiku a hudební pedagogiku. ${ }^{27}$ Ještě před odjezdem Fedora Jakymenka do Francie Steško přeložil jeho již zmíněnou učebnici harmonie z ruštiny do ukrajinštiny, což byl do značné míry pionýrský počin, jelikož ukrajinská hudebně-teoretická terminologie tehdy ještě prakticky neexistovala. ${ }^{28}$

Za dobu desetileté existence hudební fakulty zde působilo 18 pedagogů. Na katedře hudební teorie a kompozice vyučovali kromě Jakymenka také významní západoukrajinští skladatelé, odchovanci pražské konzervatoře z kompoziční třídy Josefa Suka - byl to již

22 СІМОВИЧ, Василь (ed.). Праці Українського високого педаґогічного інституту ім. Михайла Драгоманова у Празі. Драгоманівський збірник. Прага: Сіяч, 1932, s. 311-319.

23 БУЛАТ, Тамара. Уперше про Федора Якименка. Музика, 1988, № 4, s. 28-30.

24 ЯКИМЕНКО, Федір. Практичний курс науки гармонії. Прага: Український громадський видавничий фонд, 1925.

25 ЛИСьКО, Зиновій. Федір Якименко. Визначна, але малознана постать в історії української музики. Музика, 1994, № 1, s. 21-22; více o Fedoru Jakymenkovi viz KALINA, Petr Ch. Jakymenko, Fedir Stepanovyč. In Český hudební slovník osob a institucí. On-line [cit. 2019-01-01]. Dostupné z: http://www. ceskyhudebnislovnik.cz/slovnik/index.php?option=com_mdictionary\&task=record.record_detail\&cid=1003393 26 Archiv Slovanské knihovny v Praze, fond T-Drah, inv. č. 34 - Personálie - lektoři, zaměstnanci: Jakymenko, Fedir, r. 1926.

27 МАРТИНЕНКО, Оксана. Музична діяльність української еміграції у міжвоєнній Чехословаччині. Джерелознавчий аспект дослідження. Дисертація на здобуття наукового ступеня кандидата мистецтвознавства. Київ: Національна музична академія України П. І. Чайковського, 2001.

28 СТЕШКО, Федір. Моя музична біографія. In БЕДНАРЖОВА, Тетяна. Федір Стешко, український вчений-педагог, музиколог-теоретик. Тернопіль-Прага, 2000, s. 83-88. 
zmíněný Zenovij Lysko (1925-29) ${ }^{29}$ a dále Nestor Nyžankivskyj (1923-29). ${ }^{30}$ Nakrátko byl na tuto katedru ze Lvova povolán jako neplacený dočasný profesor předválečný absolvent mistrovské kompoziční školy Vítězslava Nováka Vasyl Barvinskyj (1929-30). ${ }^{31}$ Ve tř́idě sólového zpěvu učili někdejší členové Ukrajinské republikové kapely, kteří se po fenomenálním turné po Československu a dalších evropských státech v letech 1919-21 z politických důvodů již nemohli vrátit do vlasti a v Praze vystudovali konzervatoř ${ }^{32}$ Nina Ďačenko (1925-30)33 a Dmytro Levytskyj (1927-33). Dirigování učila po celou dobu existence ústavu Platonida Ščurovska. V klavírní třídě vyučovala rovněž absolventka pražské konzervatoře Vira Berezovska (1928-32), ve třídě houslí Oleksandr Kisjakiv (1924-30) a na katedře dějin hudby začal od roku 1930 učit čerstvý absolvent této školy Dmytro Ravyč. Významná byla také pedagogická činnost děkana Fedora Steška. Kromě ukrajinských emigrantů byli na škole pedagogicky činní také čeští muzikologové působící v Praze - dějiny české hudby přednášel Zdeněk Nejedlý (1925/26), dále Josef Hutter (1927-33) a hudební teorii zde učil Otakar Šín (1926-30). ${ }^{34}$ Z českých interpretů to byl pěvec a profesor pražské konzervatoře Luis Kadeřábek (1926-33). ${ }^{35}$

Hudebně-pedagogické oddělení naráželo na nedostatek kvalitních učebnic hudby v ukrajinštině, které konečně neexistovaly ani na samotné Ukrajině. Kromě Jakymenkovy učebnice harmonie vyšla také učebnice Solnyj spiv, joho teorija i praktika z pera Niny Ďačenko. K této knize je však nutno doplnit, že Zenovij Lysko v zřejmě nikdy nevydané recenzi, která je uložena v rukopisném archivu Stefanykovy vědecké knihovny ve Lvově, podrobil učebnici své kolegyně důkladnému rozboru a shledal, že jde o plagiát kompilovaný z několika existujících učebnic zpěvu. Lysko tedy konstatuje, že je tato knížka nepotřebná, protože ukrajinští studenti v Československu si mohli přečíst zmíněné publikace v češtině. ${ }^{36}$

Nezanedbatelná byla také vědecká produkce pedagogů školy; zejména Fedir Steško a Zenovij Lysko v četných studiích reflektovali především dějiny ukrajinské hudby a česko-ukrajinské hudební kontakty. ${ }^{37}$

29 KALINA, Petr Ch. Zenovij Lysko, ukrajinský žák Josefa Suka. Opus musicum, 49, 2017, č. 2, s. 25-41.

30 Archiv Slovanské knihovny v Praze, fond T-Drah, inv. č. 59 - Personálie - lektoři, zaměstnanci: Nyžankivskyj, Nestor, r. 1925-1930.

31 KALINA, Petr Ch. Vasyl Barvinskyj, ukrajinský žák Vítězslava Nováka. Opus musicum, 47, 2015, č. 1, s. $18-37$.

32 BAJGAROVÁ, Jitka - ŠEBESTA, Josef. Ukrajinští studenti na pražské konzervatoři v období první Československé republiky 1918-1938. Hudební věda, 43, 2006, č. 1, s. 39-54.

33 Archiv Slovanské knihovny v Praze, fond T-Drah, inv. č. 17 - Personálie - lektoři, zaměstnanci: Djačenko-Hordaš, Nina, r. 1926-1930; Центральний державний архів вищих органів влади та управління України, Фонд 3972, сп. 1, № 253 Особиста справа асист. Ніни Дяченко; více o Nině Ďačenko viz KALINA, Petr Ch. Ďačenko Nina. In Český hudební slovník osob a institucí. On-line [cit. 2019-01-01]. Dostupné z: http://www. ceskyhudebnislovnik.cz/slovnik/index.php?option=com_mdictionary\&task=record.record_detail\&cid=3063

34 МІРНИЙ, Іван. Український високий педагогічний інститут ім. М. Драгоманова 1923-1933. Прага: Високий педагогічний інститут за допомогою Міністерства шкільництва й народної освіти Ч.С.Р., 1934.

35 ŠTĚDROŇ, Bohumír. Kadeřábek Louis. In Československý hudební slovník osob a institucí. Svazek prvý A-L. Praha: Státní hudební vydavatelství, 1963, s. 624.

36 Львівська наукова бібліотека ім. В. Стефаника НАН України. Фонд 9 Окремі надходження, п. 547 Рукописи 3. Лиська.

37 KALINA, Petr Ch. Pražské působení ukrajinského muzikologa Fedora Steška. Musicologica Brunensia, 47, 2012, č. 2, s. 49-63; týž: Zenovij Lysko, ukrajinský žák Josefa Suka. Opus musicum, 49, 2017, č. 2, s. $25-41$. 
Ukrajinská vysoká pedagogická škola Mychajla Drahomanova (resp. její hudební oddělení) se ve své době stala ústředním organizátorem a reprezentantem ukrajinského hudebního života v meziválečné Praze. Pořádala slavnostní hudební večery, na něž zvala významné představitele československého státu včetně ministerstev. Kromě tradičních koncertů ukrajinské hudby (především na jaře při výročích úmrtí básníka Tarase Hryhorovyče Ševčenka a v zimě při příležitostech jubileí patrona školy Mychajla Drahomanova) pořádal ústav také hudební slavnosti k uctění významných představitelů české i světové hudby. ${ }^{38}$ Tyto koncerty, na kterých zněly skladby čerstvých absolventů kompozice, pedagogů ústavu i tradiční repertoár ukrajinské a české hudby, uváděl Fedir Steško a dle dobové kritiky se vyznačovaly vysokou uměleckou úrovní. ${ }^{39}$ Hlavním účastníkem koncertních setkání byl ústavní smíšený sbor pod vedením Platonidy Ščurovské.

Platonida Šrurovska vedla také Ukrajinský akademický sbor, který byl složen z ukrajinských vysokoškolských posluchačủ, kteří studovali na ukrajinských a českých vysokých školách v Praze a Poděbradech. Tento sbor vystupoval pravidelně i mimo kontext ukrajinských akcí a akademií. Například v roce 1928 zpíval v Praze na slovanském písňovém festivalu, kde obsadil první místo. ${ }^{40}$ Platonida Ščurovska byla asistentkou Oleksandra Košyce, hlavního sbormistra proslavené Ukrajinské republikové kapely, při evropském turné v letech 1919-21. ${ }^{41}$ Po rozpadu tělesa zůstala v Praze, kde vystudovala místní konzervatoř, nejprve kompozici u Jaroslava Křičky, poté sborový zpěv u Metoda Doležila. ${ }^{42}$ Na Hudebně-pedagogickém oddělení Drahomanova ústavu zastávala od roku 1925 pozici docenta ${ }^{43}$ a funkci proděkana. ${ }^{44}$

Zánik pražské Ukrajinské vysoké školy pedagogické Mychajla Drahomanova v roce 1933 souvisí s úspornými opatřeními, kdy československý stát nebyl schopen nadále financovat dvě humanitní ukrajinské vysoké školy na svém území. Aby mohla být udržena

38 Archiv Slovanské knihovny v Praze, fond T-Drah, inv. č. 404-410 - Pozvánky, oslavy, akademie, r. 1925-1931.

39 ОБІДНИЙ, М. Памяти М. Лисенка. Свято Українського Педагогічного Інституту ім. М. Драгоманова в Празі. Діло, 17. 2. 1928, № 36, s. 2-3; НИЖАНКІВСЬКИЙ, Нестор. Академія з 5-ліття Українського Педагогічного Інституту в Празі. Діло, 10. 4. 1929, № 79, s. 5; 3 українського музичного життя в Празі. І. концерт у 70-ті роковини уродин Й. Б. Ферстра. Діло, 17. 5. 1930, № 107, s. 4; 3 українського музичного життя в Празі. Діло, 18. 7. 1930, № 156, s. 5-6; Діло, 24. 12. 1930, № 284, s. 4; К. П.: 3 українського життя на чужині. Шевченківське свято у Празі. Діло, 29. 5. 1931, № 117, s. 3.

40 М. Г. Прага співає. Діло, 21. 4. 1928, № 87, s. 1-2; МАРТИНЕНКО, Оксана. Українська музична освіта в Чехії. Музично-педагогічний відділ УВПІ ім. М. Драгоманова. Український світ, 7, 1998, № 4-6, s. $30-31$.

41 KALINA, Petr Ch. Ukrajinská republiková kapela. In Český hudební slovník osob a institucí. On-line [cit. 2019-01-01]. Dostupné z: http://www.ceskyhudebnislovnik.cz/slovnik/index.php?option=com_mdictionary\&task=record.record_detail\&id=1003929

42 Центральний державний архів вищих органів влади та управління України, Фонд 3972, оп. 1, спр. 298 Особиста справа в. о. доцента Платоніди Щуровської.

43 АНТОНОВИЧ, Д. Жінка 25 літ диригентом. Назустріч, 1934, ч. 12, s. 8; více o Platonidě Ščurovské viz KALINA, Petr Ch. Ščurovska, Platonida Ivanivna. In Český hudební slovník osob a institucí. On-line [cit. 2019-01-01]. Dostupné z: http://www.ceskyhudebnislovnik.cz/slovnik/index.php?option=com_mdictionary\&task=record.record_detail\&id=1003395

44 МІРНИЙ, Іван. Український високий педагогічний інститут ім. М. Драгоманова 1923-1933. Прага: Високий педагогічний інститут за допомогою Міністерства шкільництва й народної освіти Ч.C.P., 1934. 
existence Ukrajinské svobodné univerzity, bylo rozhodnuto o ukončení činnosti menší a úžeji zaměřené pedagogické vysoké školy. Už od poloviny 20. let 20. století se začaly dotace od československého státu směřované emigrantským institucím výrazně seškrtávat a ukrajinská pedagogická škola začala zápasit o vlastní existenci. Československé Ministerstvo zahraničních věcí už v akademickém roce 1925/26 odmítalo otevřít první ročníky školy, jeho rozhodnutí se ještě podařilo zvrátit, noví studenti však zahájili výuku až v prosinci $1925 .{ }^{45}$ Od 1. ledna 1928 přestal Drahomanovův ústav spadat pod Ministerstvo zahraničí a byl zařazen do gesce Ministerstva školství a národní osvěty. „Zatímco proni z uvedených ministerstev si bylo určitým zpưsobem vědomo, že emigrantské školy v ČSR vyžaduji zvláštni zacházeni, druhé $k$ nim přistupovalo stejně jako k jiným tuzemským školám. "46 Skončilo tak výjimečné postavení ústavu v rámci československého školství. Tehdy už bylo rozhodnuto o postupném ukončování činnosti školy. Ministerstvo školství ještě dva roky povolovalo přijímat studenty do prvních ročníků, z důvodu značně redukovaného rozpočtu školy už však pouze bez nároku na stipendium, což výrazně snížilo počet zájemců o studium. Od roku 1930 ministerstvo finančně podporovalo již pouze pedagogy, kteří byli držiteli tzv. Nansenových pasů, tedy skutečné emigranty bez jakékoliv státní příslušnosti. Z tohoto důvodu odešel z učitelského sboru Hudebně-pedagogického oddělení český muzikolog Otakar Šín a nechybělo mnoho a školu opustil i Josef Hutter, který se však nakonec rozhodl, že bude na hudební oddělení nadále docházet bez nároku na honorár. ${ }^{47}$ Podobně musela školu v roce 1930 opustit lektorka klavíru Vira Berezovská, která získala československé občanství. ${ }^{48}$ Zároveň byl vydán zákaz přijímání nových studentů a k 1. březnu 1933 měl ústav svou činnost definitivně ukončit. Bez výsledku zůstaly i četné intervence vedení školy na ministerstvu i v kanceláři prezidenta republiky, v nichž se výrazně angažoval i děkan Hudebně-pedagogického oddělení Fedir Steško. Pedagogický ústav se také snažil odvrátit své úplné zrušení tím, že by byl přeměněn ve vědecko-výzkumnou instituci, která by reflektovala československo-ukrajinské vztahy v minulosti i př́itomnosti a zaměřila svou odbornou pozornost také na oblast Podkarpatské Rusi. Tímto měla být zachována pracovní místa alespoň pro některé z učitelů školy. $\mathrm{Z}$ tohoto důvodu Drahomanovův ústav v posledních letech existence výrazně zintenzivnil svou konferenční a publikační činnost. ${ }^{49}$ Ani tento plán však nevyšel a ústav na počátku roku 1933 bez náhrady zanikl. Nepomohlo ani memorandum zaslané profesorským sbo-

45 HAVEL, Ondřej. Osudy ukrajinské emigrace v první československé republice se zaměřením na vysoké školství (Ukrajinský vysoký pedagogický institut Mychajla Drahomanova). Disertační práce, Filozofická fakulta Univerzity Palackého v Olomouci, Olomouc 2012.

46 Ibid., s. 86.

47 Archiv Slovanské knihovny v Praze, fond T-Drah, inv. č. 30 - Personálie - lektoři, zaměstnanci: Hutter, Josef, r. 1930.

48 МІРНИЙ, Іван. Український високий педагогічний інститут ім. М. Драгоманова 1923-1933. Прага: Високий педагогічний інститут за допомогою Міністерстві шкільництва й народної освіти Ч.С.Р., 1934.

49 СІМОВИЧ, Василь (ed.). Праці Українського високого педагогічного інституту ім. Михайла Драгоманова у Празі. Т. 1. Прага: Видання Укр. висок. пед. інституту, 1929; СІМОВИЧ, Василь (ed.). Праці Українського високого педагогічного інституту ім. Михайла Драгоманова у Празі. Драгоманівський збірник. Прага: Сіяч, 1932; СІМОВИЧ, Василь (ed.). Праці Українського високого педагогічного інституту ім. Михайла Драгоманова у Празі. Т. 2. Прага: Видання Укр. висок. пед. інституту, 1934. 
rem na adresu ministra zahraničí Edvarda Beneše, v němž bylo zdůrazněno, že původní ideje ústavu nemohly být uskutečněny nikoliv vinou nevyhovující práce jeho zaměstnanců, nýbrž kvůli neutěšené finanční situaci československého státu v době po velké hospodářské krizi. Školní knihovna čítající 10728 publikací byla z větší části předána Ukrajinskému gymnáziu a dílem do pražské Slovanské knihovny. Ostatní majetek školy byl věnován Ukrajinské vědecké asociaci, Muzeu osvobozeneckého boje Ukrajiny a Ukrajinské svobodné univerzitě. Bez práce se ocitlo 29 někdejších učitelů školy, většina z nich ovšem i po svém propuštění dostávala od státu pravidelnou finanční podporu. Bývalí zaměstnanci ústavu nacházeli útočiště především v Ukrajinském gymnáziu v Modřanech (z Hudebně-pedagogického oddělení to byla Platonida Ščurovska-Rosinevyč, která sem ovšem nastoupila až v roce 1937 a Nina Ďačenko), kde konečně pracovali i někteří absolventi ústavu, nebo na Ukrajinské svobodné univerzitě50 (jak již bylo řečeno, zde se už od akademického roku 1923/24 paralelně uplatňoval Fedir Steško)..$^{51}$

Likvidací Ukrajinské vysoké školy Mychajla Drahomanova skončilo systematické ukrajinské vzdělávání v hudbě na území Československa, jež ve svém původním rozsahu nebylo už nikdy obnoveno. V kontextu ukrajinského vysokého školství v oblasti hudby není bez zajímavosti, že se na pražském Drahomanovově ústavu poprvé a dosud naposled vyučovalo hudbě z univerzitních pozic, tedy v úzkém kontaktu s ostatními humanitními a společenskovědními disciplínami tak, jak to bylo a je běžné v západní Evropě, a nikoliv z pozic konzervatorních, kdy je hudební věda a hudební pedagogika součástí vyučování výhradně na uměleckých akademiích, což je dosud běžná praxe v postsovětském prostoru, Ukrajinu nevyjímaje.

Stat' vznikla s finanční podporou Grantového fondu děkana Filozofické fakulty $M U$.

50 HAVEL, Ondřej. Osudy ukrajinské emigrace v první československé republice se zaměřením na vysoké školství (Ukrajinský vysoký pedagogický institut Mychajla Drahomanova). Disertační práce, Filozofická fakulta Univerzity Palackého v Olomouci, Olomouc 2012.

51 Центральний державний архів вищих органів влади та управління України, Фонд 3972, оп. 1, спр. 288 Особиста справа в. о. доцента Стешка Федора. 


\section{Bibliography}

\section{Sources}

Archiv Slovanské knihovny v Praze, fond T-Drah, inv. č. 17 - Personálie - lektoři, zaměstnanci: Djačenko-Hordaš, Nina, r. 1926-1930.

Archiv Slovanské knihovny v Praze, fond T-Drah, inv. č. 30 - Personálie - lektoři, zaměstnanci: Hutter, Josef, r. 1930.

Archiv Slovanské knihovny v Praze, fond T-Drah, inv. č. 34 - Personálie - lektoři, zaměstnanci: Jakymenko, Fedir, r. 1926.

Archiv Slovanské knihovny v Praze, fond T-Drah, inv. č. 59 - Personálie - lektoři, zaměstnanci: Nyžankivskyj, Nestor, r. 1925-1930.

Archiv Slovanské knihovny v Praze, fond T-Drah, inv. č. 404 - Pozvánky, oslavy, akademie, r. 1925. Archiv Slovanské knihovny v Praze, fond T-Drah, inv. č. 405 - Pozvánky, oslavy, akademie, r. 1926. Archiv Slovanské knihovny v Praze, fond T-Drah, inv. č. 406 - Pozvánky, oslavy, akademie, r. 1927. Archiv Slovanské knihovny v Praze, fond T-Drah, inv. č. 407 - Pozvánky, oslavy, akademie, r. 1928. Archiv Slovanské knihovny v Praze, fond T-Drah, inv. č. 408 - Pozvánky, oslavy, akademie, r. 1929. Archiv Slovanské knihovny v Praze, fond T-Drah, inv. č. 409 - Pozvánky, oslavy, akademie, r. 1930. Archiv Slovanské knihovny v Praze, fond T-Drah, inv. č. 410 - Pozvánky, oslavy, akademie, r. 1931. Львівська наукова бібліотека ім. В. Стефаника НАН України. Фонд 9 Окремі надходження, п. 547 Рукописи 3. Лиська.

Центральний державний архів вищих органів влади та управління України, Фонд 3859, оп. 1, спр. 176: Справа про захист дисертацій докторандами університету.

Центральний державний архів вищих органів влади і управління України. Ф. 3956, оп. 1, спр. 33: Дисертація С. Туркевич-Лісовської «Українські елементи в операх Чайковського Черевички та Римського-Корсакова Ніч перед Різдвом і порівнання їх з оперою Лисенка Різдвяна ніч».

Центральний державний архів вищих органів влади та управління України, Фонд 3972, оп. 1, спр. 176 Постановка професорської ради про дипломні іспити.

Центральний державний архів вищих органів влади та управління України, Фонд 3972, сп. 1, № 253 Особиста справа асист. Ніни Дяченко.

Центральний державний архів вищих органів влади та управління України, Фонд 3972, оп. 1, спр. 288 Особиста справа в. о. доцента Стешка Федора.

Центральний державний архів вищих органів влади та управління України, Фонд 3972, оп. 1, спр. 298 Особиста справа в. о. доцента Платоніди Щуровської.

\section{Literature}

BAJGAROVÁ, Jitka - ŠEBESTA, Josef. Ukrajinští studenti na pražské konzervatoři v období první Československé republiky 1918-1938. Hudebni věda, 43, 2006, č. 1, s. 39-54.

HAVEL, Ondřej. Osudy ukrajinské emigrace v pruni československé republice se zaměrenením na vysoké školství (Ukrajinský vysoký pedagogický institut Mychajla Drahomanova). Disertační práce, Filozofická fakulta Univerzity Palackého v Olomouci, Olomouc 2012. 
KALINA, Petr Ch. Ďačenko Nina. In Český hudebni slovnik osob a institucí. On-line [cit. 2019-01-01]. Dostupné z: http://www.ceskyhudebnislovnik.cz/slovnik/index.php?option=com_mdictionary\&task=record.record_detail\&id=3063

KALINA, Petr Ch. Jakymenko, Fedir Stepanovyč. In Český hudebni slovnik osob a instituci. On-line [cit. 2019-01-01]. Dostupné z: http://www.ceskyhudebnislovnik.cz/slovnik/index.php?option=com_mdictionary\&task=record.record_detail\&id=1003393

KALINA, Petr Ch. Pražské působení ukrajinského muzikologa Fedora Steška. Musicologica Brunensia, 47, 2012, č. 2, s. 49-63.

KALINA, Petr Ch. Ščurovska, Platonida Ivanivna. In Český hudebni slovnik osob a institucí. On-line [cit. 2019-01-01]. Dostupné z: http://www.ceskyhudebnislovnik.cz/slovnik/index.php?option=com_mdictionary\&task=record.record_detail\&id=1003395

KALINA, Petr Ch. Vasyl Barvinskyj, ukrajinský žák Vítězslava Nováka. Opus musicum, 47, 2015, č. 1, s. 18-37.

KALINA, Petr Ch. Ukrajinská republiková kapela. In Český hudebni slovnik osob a institucí. On-line [cit. 2019-01-01]. Dostupné z: http://www.ceskyhudebnislovnik.cz/slovnik/index.php?option=com_mdictionary\&task=record.record_detail\&id=1003929

KALINA, Petr Ch. Zenovij Lysko, ukrajinský žák Josefa Suka. Opus musicum, 49, 2017, č. 2, s. 25-41.

RYCHLÍK, Jan - ZILYNSKYJ, Bohdan - MAGOCSI, Paul Robert. Dějiny Ukrajiny. Praha: Nakladatelství Lidové noviny, 2015.

ŠTĚDROŇ, Bohumír. Kadeřábek Louis. In Československý hudebni slovnik osob a institucí. Svazek prvý A-L. Praha: Státní hudební vydavatelství, 1963, s. 624.

АНТОНОВИЧ, Д. Жінка 25 літ диригентом. Назустріч, 1934, ч. 12, s. 8.

БУЛАТ, Тамара. Уперше про Федора Якименка. Музика, 1988, № 4, s. $28-30$.

3 украйнського музичного життя в Празі. І. кончерт у 70-ті роковини уродин Й. Б. Ферстра. Діло, 17. 5. 1930, № 107, s. 4.

3 украӥнського музичного життя в Празі. Діло, 18. 7. 1930, № 156, s. 5-6.

Імені Драгоманова. До 75-ї річниці заснування Українського Високого Педагогічного Інституту в Празі. Украӥнський світ, 7, 1998, № 4-6, s. 13.

К. П. З украӥнського життя на чужині. Шевченківське свято у Празі. Діло, 29. 5. 1931, № 117, s. 3.

ЛИСьКО, Зиновій. Федір Якименко. Визначна, але малознана постать в історії української музики. Музика, 1994, № 1, s. 21-22.

М. Г. Прага співає. Діло, 21. 4. 1928, № 87, s. 1-2.

МАРТИНЕНКО, Оксана. Музична діяльність украйнської емігращї у міжвоєнній Чехословаччині. Джерелознавчий аспект дослідженя. Дисертація на здобуття наукового ступеня кандидата мистецтвознавства. Київ: Національна музична академія України П. І. Чайковського, 2001.

МАРТИНЕНКО, Оксана. Українська музична освіта в Чехії. Музично-педагогічний відділ УВПІ ім. М. Драгоманова. Украӥнський світ, 7, 1998, № 4-6, s. 30-31.

МАЦЕНКО, Павло. Якименко Федір Степанович. Вінніпег: Культура й Освіта, 1954.

МАРУНЯК, В. (еd.). Українська гімназія в Чехї. 1925-1945. Альманах Украйнської гімназї в Празі - Ржевнічах - Модржанах. München 1975.

МІРНИЙ, Іван. Украйнсвкий високий педагогічний інститут ім. М. Драгоманова 1923-1933 (історія інституту). Прага: Високий педагогічний інститут за допомогою Міністерства шкільництва й народної освіти Ч.С.Р.,1934.

НАРІЖНИЙ, Симон. Украӥнська еміграчія. Культурна праия украӥнської еміграиї̈між двома світовими війнами. Ч. 1. Прага: Knihtisk, 1942.

НАРІЖНИЙ, Симон. Украӥнська еміграчія. Культурна прахя украйнської еміграиї 1919-1939. Ч. 2. Київ: Видавнициво ім. Олени Теліги, 1999. 
НИЖАНКІВСЬКИЙ, Нестор. Академія з 5-ліття Украӥнсъкого Педагогічного Інституту в Празі. Діло, 10. 4. 1929, № 79, s. 5.

ОБІДНИЙ, М. Памяти М. Лисенка. Свято Украӥнського Педагогічного Інституту ім. М. Драгома нова в Празі. Діло, 17. 2. 1928, № 36, s. 2-3.

СІМОВИЧ, Василь (еd.). Праиі Украйнського високого педагогінного інституту ім. Михайла Драгоманова у Празі. Т. 1. Прага: Видання Укр. висок. пед. інституту, 1929.

СІМОВИЧ, Василь (еd.). Прахі Украӥнсъкого високого педагогічного інституту ім. Михайла Драгоманова у Празі. Драгоманівський збірник. Прага: Сіяч, 1932.

СІМОВИЧ, Василь (еd.). Праиі Украӥнсъкого високого педагогінного інституту ім. Михайла Драгоманова у Празі. Т. 2. Прага: Видання Укр. висок. пед. інституту, 1934.

СТЕШКО, Федір. Моя музична біографія. In БЕДНАРЖОВА, Тетяна. Федір Стешко, украйнсъкий вчений-педагог, музиколог-теоретик. Тернопіль-Прага, 2000, s. 83-88.

Украйнський вільний університет. Короткий огляд. Мюнхен: Український вільний університет, 1958 / Ukrainian Free University. Short Review. Munich: Ukrainian Free University Press, 1958.

Украйнський вільний університет в Прахі, в роках 1921-1922. Прага: Державна друкарня, 1924.

ЯКИМЕНКО, Федір. Практинний курс науки гармоніӥ. Прага: Український громадський видавничий фонд, 1925. 